\title{
DIESEL ENGINE PERFORMANCE, EMISSION AND COMBUSTION CHARACTERISTICS WITH OPTIMIZED BLEND OF B25 METHYL ESTER OF MANGO SEED OIL
}

\author{
K. Vijayaraj* \\ Principal, Priyadarshini Engineering College, \\ Vaniyambadi, Tamil Nadu, India. \\ A. Muruga Ganesan \\ Associate Professor, Department of Mechanical Engineering, \\ Annamalai University, Tamil Nadu, India.

\section{C.G. Saravanan} \\ Professor, Department of Mechanical Engineering, \\ Annamalai University, Tamil Nadu, India. \\ *Corresponding Author Email:kvr28212@gmail.com
}

\begin{abstract}
Oil based fuels worldwide have not just brought about the speedy consumption of available energy sources, yet have likewise caused extreme air pollution. The quests for a substitute fuel has prompted numerous findings because of which wide assortment of alternative fuels are available now. The current investigations have revealed the utilization of vegetable oils for engines as an option for diesel fuel. Since there is a restriction in using vegetable oils in diesel engines because of their high viscosity and low volatility. In the current work, mango seed oil is converted into respective methyl ester by trans esterification process. Tests are conducted using different blends of methyl ester of mango seed oil with diesel in a diesel engine. The investigation consequences demonstrated that the MEMSO biodiesel has comparable qualities to that of diesel. The brake thermal efficiency and smoke are seen to be lower in case of MEMSO biodiesel blends than diesel. Then again, BSFC and NOx of MEMSO biodiesel blends are seen as higher than diesel. It is observed that the combustion characteristics of methyl ester of mango seed oil blends seem to be similar with that of the diesel. From this investigation, it is concluded that B25 as optimized blend and could be used as an alternative fuel in a diesel engine with no engine modifications.
\end{abstract}

Keywords: Biodiesel, methyl ester of mango seed oil, performance, emission, combustion. 
Cite this Article: K. Vijayaraj, A. Muruga Ganesan, C.G. Saravanan, Diesel Engine Performance, Emission and Combustion Characteristics with Optimized Blend of B25 Methyl Ester of Mango Seed Oil. International Journal of Mechanical Engineering and Technology. 11(5), 2020, pp. 1-11.

https://iaeme.com/Home/issue/IJMET?Volume $=11 \&$ Issue $=5$

\section{INTRODUCTION}

The crude oil and petroleum products are importing from Gulf countries for India. Presently Indian scientists seek for an alternate to petroleum fuels to preserve the environment and to overcome the economical crisis. Fuels of bio origin can be taken as an alternative renewable fuel to run the IC engines. Vegetable oils from plants both edible, non-edible and methyl esters (Biodiesel) are used as an alternate source for diesel fuel. Biodiesel was found to be the best alternate fuel, technically, environmentally acceptable, economically competitive and easily available. There are more than 350 oil bearing crops that have been identified, among which only sunflower, soyabean, cottonseed, mango seed, rapeseed and peanut oils are considered as potential alternative fuels for diesel engines. Apart from the renewability, the advantages of biofuel are: High oxygen content, higher flash point and higher lubricity that produce complete combustion in comparison with conventional diesel fuel [1]. Further, the environmental benefit is another investigation factor due to lesser green house effect, less air pollution, less contamination of water, soil and reduced health risk [2]. Traditional oilseed feedstock for biodiesel production predominantly includes soyabean, rapeseed/canola, palm, corn, sunflower, cottonseed, peanut and coconut oil [3]. The long chain hydrocarbon structure, vegetable oils have good ignition characteristics, however they cause serious problems such as carbon deposits build up, poor durability, high density, high viscosity, lower calorific value, more molecular weight and poor combustion. These problems lead to poor thermal efficiency, while using vegetable oil in the engine. These problems can be rectified by different methods which are used to reduce the viscosity of vegetable oils. The methods are transesterification, dilution and cracking method [4]. The transesterification of vegetable oil gives better performance when compared to straight vegetable oil [5]. Many researches are focused on non-edible oils which are not suitable for human consumption due to the presence of toxic components present in the oil. Moreover, the non-edible oil crops grow in waste lands which are not suitable to use as food [6,7]. The increase in brake thermal efficiency and lower in specific fuel consumption were observed in a diesel engine fuelled with Calophyllum Inophyllum (punnai) biodiesel and additives [8]. The diesel engine performance parameters were higher and lower in emissions while operating with B20 blend biodiesel [9]. Rakopoulos et.al.[10] studied the use of four straight vegetable oils like sunflower, cotton seed, olive and corn oils on mini-bus engine and reported that olive oil has very high content of the unsaturated oleic acid (one double carbon bond) and very low content of the unsaturated linoleic acid (two double carbon bonds), in contrast with the other three vegetable linoleic acids. Further, the cotton seed oil has the highest content of palmitic acid (saturated). These may play some role in the soot formation and oxidation mechanism. Saravanan et al. [11] reported that pure Mahua oil methyl ester (B100) gives the lower emissions as compared with neat diesel (B0) in a DI diesel engine. The performance of diesel engine with rice bran oil methyl ester and its diesel blends resulted in increase of $\mathrm{CO}, \mathrm{HC}$ and soot emissions and slight increase of NOx with increase in blends compared to diesel Also the ignition delay and peak heat release rate for RBME were lower for biodiesel and it was increased with increase in RBME blends [12]. Rajan et al [13] have investigated the performance of a diesel engine with internal jet piston using biodiesel and observed increase in brake thermal efficiency and decrease in $\mathrm{CO}$ and smoke emissions at full load, whereas $\mathrm{NO}_{\mathrm{x}}$ emission is increased at full load compared to diesel fuel. Sharanappa et al [14] investigated the use of Mahua oil methyl ester and its diesel 
Diesel Engine Performance, Emission and Combustion Characteristics with Optimized Blend of B25 Methyl Ester of Mango Seed Oil

blends as an alternative fuel in a hevy duty diesel engine and observed that B20 blend gives better performance and lower emissions. The methyl ester of Thevetia peruviana seed oil (METPSO) results lower emission of $\mathrm{CO}, \mathrm{HC}$ and higher $\mathrm{NO}_{\mathrm{x}}$ as compared to that of diesel [15]. The cylinder peak Pressure of soyabean biodiesel is close to that of diesel and also the peak rate of pressure rise and peak heat release rate during premixed combustion are lower for biodiesel [16].

The use of biodiesel in India will lead to many advantages like green cover to waste land, support to agriculture, rural economy, reduction in dependence on imported crude oil and reduction in air pollution [17]. Currently, India is spending about Rs.80,000 million per year for importing $70 \%$ of petroleum fuels and produces only $30 \%$ of the total fuel requirements. It is estimated that mixing of $5 \%$ of biodiesel fuel to the present diesel fuel can save Rs.40,000 million per year. The aim of the present investigation is the preparation of biodiesel from mango seed oil and to study the performance, emission and combustion characteristics of a diesel engine using biodiesel and its various blends and compared with diesel.

\section{BIODIESEL PRODUCTION AND CHARACTERIZATION}

\subsection{Biodiesel Production}

The production of biodiesel from mango seed oil is done by transesterification process. It is the process of reacting the mango seed oil with methanol in the presence of catalyst $(\mathrm{KOH})$. During the process, the molecule of mango seed oil is chemically broken to form methyl ester of mango seed oil (biodiesel). The biodiesel is filtered to separate from glycerol. A maximum of $850 \mathrm{ml}$ methyl ester of mango seed oil production is observed for 1 litre of raw mango seed oil, $250 \mathrm{ml}$ of methanol and $12 \mathrm{gm}$ of potassium hydroxide at $60^{\circ} \mathrm{C}$.

\subsection{Biodiesel Properties}

A series of tests are conducted to characterize the properties and fatty acid composition of the produced biodiesel. The properties and compositions of biodiesel and its blends with diesel fuel are shown in Table $1 \& 2$ respectively.

Table 1 Properties of biodiesel in comparison with diesel and best blend (Source: Laboratory evaluation at Eta- lab, Chennai)

\begin{tabular}{|l|c|c|c|}
\hline \multicolumn{1}{|c|}{ Property } & Diesel & B 25 & B 100 \\
\hline Specific gravity @ $15^{\circ} \mathrm{C}$ & 0.829 & 0.846 & 0.895 \\
\hline Kinematic Viscosity @ $40^{\circ} \mathrm{C}$ in cSt & 2.57 & 3.33 & 5.6 \\
\hline Density @ $15^{\circ} \mathrm{C}\left(\mathrm{kg} / \mathrm{m}^{3}\right)$ & 828 & 845 & 894 \\
\hline Flash point ${ }^{\circ} \mathrm{C}$ & 53 & 82 & 168 \\
\hline Fire point ${ }^{\circ} \mathrm{C}$ & 59 & 88 & 174 \\
\hline Gross Calorific Value $(\mathrm{kJ} / \mathrm{kg})$ & 44,680 & 43,729 & 40,874 \\
\hline Cetane Number & 51 & 51.3 & 52 \\
\hline
\end{tabular}

It is shown that the viscosity of biodiesel is evidently higher than that of diesel fuel. The density of the biodiesel is approximately $8 \%$ higher than that of diesel fuel. The gross calorific value is approximately $8.5 \%$ lower than that of diesel. Therefore, it is necessary to increase the fuel amount to be injected into the combustion chamber to produce the same 
amount of power. Fuels with flash point $52^{\circ} \mathrm{C}$ are regarded as safe. Thus, biodiesel is an extremely safe fuel to handle when compared to diesel. B25 has a flash point much above that of diesel; making biodiesel a preferable choice as far as safety is concerned.

The fatty acid composition of the oils seems to have an important role in the performance of the biodiesel in diesel engines [18]. The higher level of unsaturated fatty acid reduces fuel quality, because of its easy oxidation [19]. The saturated fatty acid such as16:0 or 18:0 are stable than unsaturated ones like 18:1, 18:2 and 18:3 which decreases the fuel quality [20]. Gopinath et al [21] reported that biodiesel with more percentage of unsaturated fatty acids emits lower $\mathrm{HC}, \mathrm{CO}$ and smoke, higher $\mathrm{NO}_{\mathrm{x}}$ than that of saturated biodiesel. The biodiesel with more unsaturated fatty acid has lower cetane number and heating value respectively. From the Table 2, it is observed that MEMSO (B100) contains optimum of $69.44 \%$ of unsaturated fatty acids, which implies that it can be used as fuel in a diesel engine.

Table 2 Fatty acid composition of biodiesel (Source: Laboratory evaluation at SGS-lab, Thane)

\begin{tabular}{|c|c|c|c|c|}
\hline \multirow{2}{*}{ Type } & \multicolumn{3}{|c|}{ Fatty Acid } & MEMSO \\
\hline \multirow{4}{*}{ UNSATURATD } & 1. & Oleic & $18: 1$ & 37.29 \\
\cline { 2 - 5 } & 2. & Linoleic & $18: 2$ & 32.15 \\
\cline { 2 - 5 } & 3. & Palmitoleic & $16: 1$ & $<0.01$ \\
\hline \multirow{5}{*}{ SATURATED } & 4. & Lauric & $12: 0$ & $<0.01$ \\
\cline { 2 - 5 } & 5. & Palmitic & $16: 0$ & 24.73 \\
\cline { 2 - 5 } & 6. & Stearic & $18: 0$ & 4.07 \\
\cline { 2 - 5 } & 7. & Arachidic & $20: 0$ & 0.42 \\
\cline { 2 - 5 } & 8. & Myristic & $14: 0$ & 0.49 \\
\cline { 2 - 5 } & 9. & Margaric & $17: 0$ & $<0.01$ \\
\hline
\end{tabular}

\section{EXPERIMENT}

\subsection{Equipment and Method}

The Kirloskar TAF 1 engine was used in the experiment and its specification are shown in Table 3. The layout of the experimental setup is shown in Fig.1. An eddy current dynamometer was connected with the engine and used to measure engine power. An exhaust gas analyser MRU DELTA 1600-L was employed to measure $\mathrm{NO}_{\mathrm{x}}, \mathrm{HC}, \mathrm{CO}, \mathrm{O}_{2}$ and $\mathrm{CO}_{2}$ emission on line. To ensure the measured values were high, the gas analyser was calibrated before each measurement using reference gases.

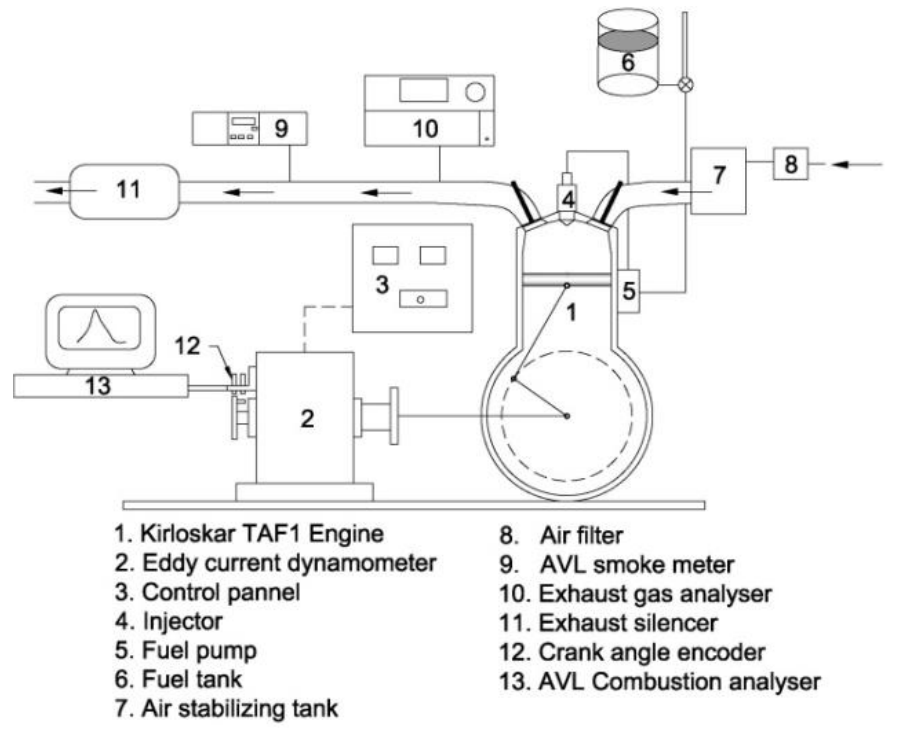

Figure 1.Layout of Experimental setup 
The AVL smoke meter was used to measure the smoke density. The smoke meter was also allowed to adjust its zero point before each measurement. The AVL combustion analyser was used to measure the combustion characteristics of the engine.

Table 3 Specifications of the test engine

\begin{tabular}{ll}
\hline Make and Model & $:$ Kirloskar TAF 1 \\
Type & $:$ Four stroke, DI Diesel Engine \\
Bore Stroke & $: 87.5 \mathrm{~mm} \times 110 \mathrm{~mm}$ \\
Compression ratio & $: 17.5: 1$ \\
Swept volume & $: 661 \mathrm{~cm}^{3}$ \\
Connecting rod length & $: 220 \mathrm{~mm}$ \\
Rated power & $: 4.4 \mathrm{~kW}$ \\
Rated speed & $: 1500 \mathrm{rpm}$ \\
Start of injection & $: 23^{\circ} \mathrm{bTDC}$ \\
Injection pressure & $: 200 \mathrm{bar}$ \\
\hline
\end{tabular}

\subsection{Engine Test Procedure}

The experiments were carried out by using diesel as the base line fuel (B0), $25 \%$ biodiesel + $75 \%$ diesel (B25), 50\% biodiesel $+50 \%$ diesel (B50), $75 \%$ biodiesel $+25 \%$ diesel (B75) and $100 \%$ neat biodiesel (B100) at different loads from $0 \%$ to $100 \%$ of rated engine load in steps of $25 \%$. Before running the engine to a new fuel, it was allowed to run for sufficient time to consume the remaining fuel of the previous experiment.

To evaluate the performance parameters, the important operating parameters such as engine speed, power output, fuel consumption, exhaust emissions and cylinder pressure were measured. Significant engine performance parameters such as brake specific fuel consumption (BSFC) and brake thermal efficiency (BTE) for biodiesel and its blends were calculated.

\section{RESULTS AND DISCUSSIONS}

\subsection{Performance Characteristics}

The significant engine performance parameters such as BTE and BSFC are evaluated for MEMSO and diesel. The BSFC is an ideal parameter for comparing the engine performance of fuels having different calorific values and specific gravities. BSFC is the ratio between the mass flow rate of the tested fuel and effective power.

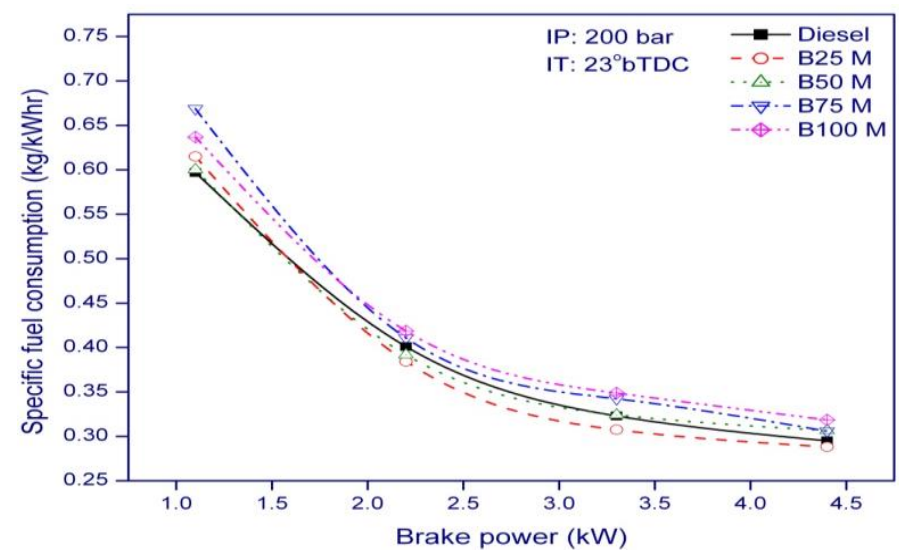

Figure 2 Variation of BSFC with BP 
The Fig. 2 shows the BSFC variation of the biodiesel and its blends with respect to brake power of the engine. The BSFC of the engine with neat MEMSO (B100) is higher when compared to B25, B50, B75 and diesel at all loads. The lowest BSFC's are 0.29, 0.3, 0.31, 0.33 and $0.34 \mathrm{~kg} / \mathrm{kW}$ h for B0, B25, B50, B75 and B100 respectively. This may be due to lower heating value, higher viscosity and density of MEMSO. The primary reason is, increase in BSFC with increase in fuel blends is the additional consumption of biodiesel fuel by the test engine in order to maintain constant power output [22].

Brake thermal efficiency (BTE) is the ratio between the power output and the energy introduced through fuel injection, the latter being the product of the injected fuel mass flow rate and the lower heating value. The brake thermal efficiency plots in Fig. 3 show an increase of brake thermal efficiency with an increase in the engine load as the amount of diesel in the blend increases. Even a small quantity of diesel in the blend improves the performance of the engine. The brake thermal efficiency of the B25 blend is better than other blends, which is very closer to diesel. This is due to reduction in viscosity which leads to improved atomization, vaporization and combustion. Due to a faster burning of biodiesel in the blend (B25), the thermal efficiency improved. The value is $28.13 \%$ as against $28.56 \%$ for diesel at 100\% load. The highest BTE's are 28.56, 28.13, 27.6, 27.44 and $26.82 \%$ for B0, B25, B50, $\mathrm{B} 75$ and B100 respectively.

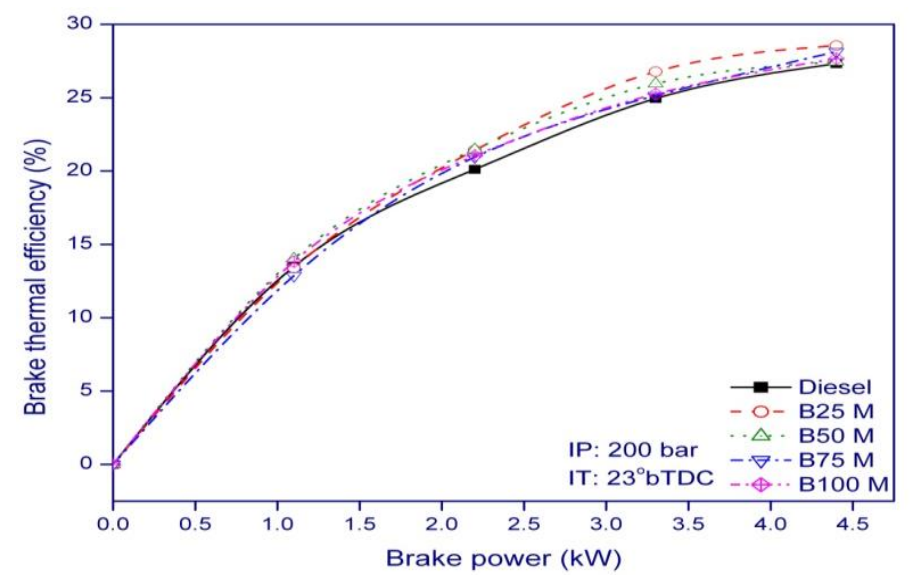

Figure 3 Variation of BTE with BP

\subsection{Emission Characteristics}

The variation of $\mathrm{NO}_{\mathrm{x}}$ with brake power for diesel, biodiesel and its blends are shown in Fig.4. Three factors that affect the formation of $\mathrm{NO}_{\mathrm{x}}$ in the cylinder are oxygen content, combustion flame temperature and reaction time. $\mathrm{NO}_{\mathrm{x}}$ emissions of biodiesel and its blends are slightly higher than those of diesel fuel. The higher temperature of combustion and the presence of oxygen with biodiesel cause higher $\mathrm{NO}_{\mathrm{x}}$ emissions, especially at high engine loads. $\mathrm{NO}_{\mathrm{x}}$ emissions were found to increase due to the presence of extra oxygen in the molecules of biodiesel blends [23].

However, the biodiesel with higher cetane number had comparable $\mathrm{NO}_{\mathrm{x}}$ emissions with the diesel fuel. A higher cetane number would result in a shortened ignition delay period, thereby allowing less time for the air-fuel mixing before the pre-mixed combustion phase. Consequently, a weaker mixture would be generated and burnt during the premixed combustion phase resulting in relatively reduced $\mathrm{NO}_{\mathrm{x}}$ formation. 
Diesel Engine Performance, Emission and Combustion Characteristics with Optimized Blend of B25 Methyl Ester of Mango Seed Oil

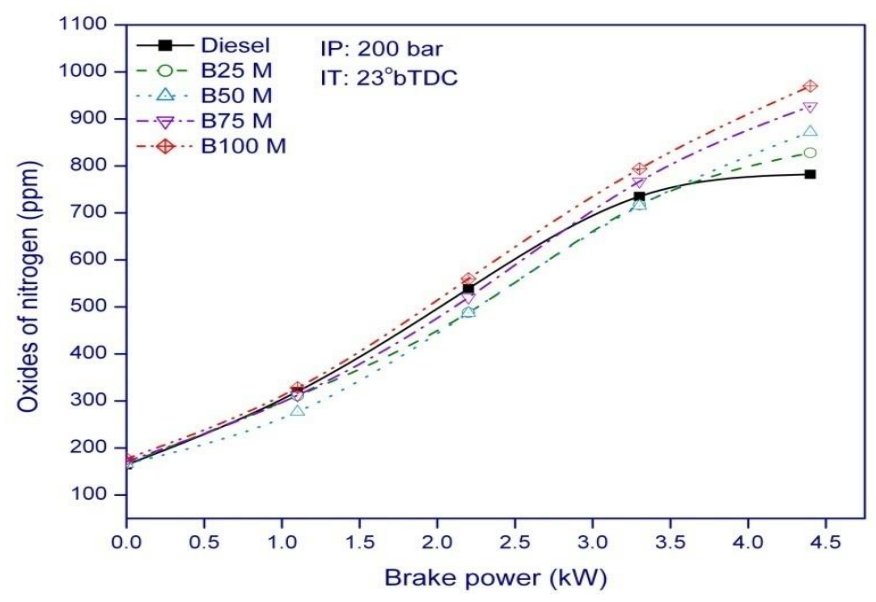

Figure 4 Variation of $\mathrm{NO}_{\mathrm{x}}$ with $\mathrm{BP}$

The lowest $\mathrm{NO}_{\mathrm{x}}$ emissions are 782, 828, 872, 927 and 970 ppm for B0, B25, B50, B75 and $\mathrm{B} 100$ respectively. From the figure, it is clear that at full load, $\mathrm{NO}_{\mathrm{x}}$ emission for $\mathrm{B} 100$ was $24 \%$ higher than that of diesel whereas for $\mathrm{B} 25$, the $\mathrm{NO}_{\mathrm{x}}$ emission was $5.88 \%$ higher. $\mathrm{NO}_{\mathrm{x}}$ emission is the most harmful gaseous emissions from the engines; the reduction of it is always the target of engine researchers and engine manufacturers. Reduction of $\mathrm{NO}_{\mathrm{x}}$ with biodiesel may be possible with the proper adjustment of injection timing and by introducing exhaust gas recirculation (EGR) or selective catalytic reduction technology (SCR).

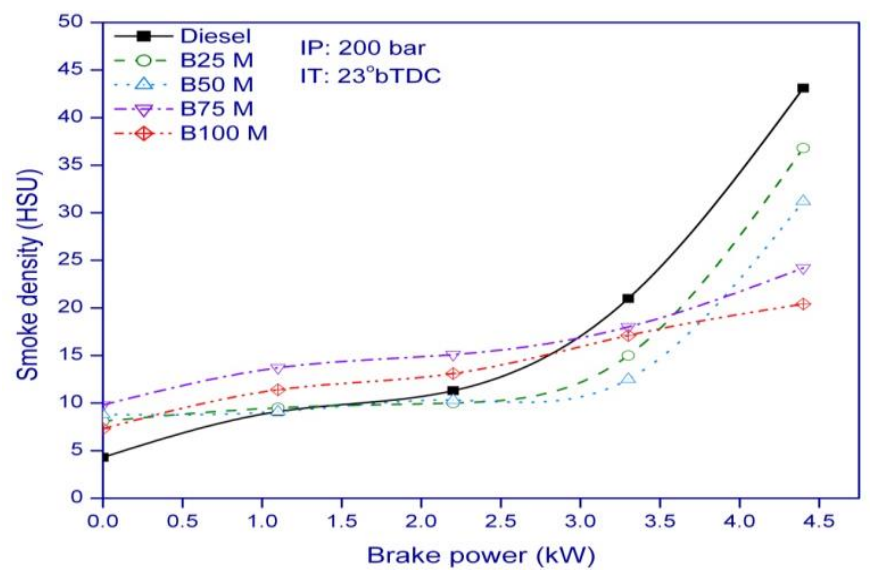

Figure 5 Variation of smoke density with BP

There is a significant reduction in smoke emission of $43.85 \%$ for B100 at full load compared to diesel because of its oxygenated nature. But at low and middle engine loads the smoke density is higher than diesel. This is due to the high viscosity of biodiesel, which results in poor atomization and locally rich mixtures at part load operations. But at high engine loads, smoke density of biodiesel and its blends is lower than diesel fuel. Smoke is mainly produced in the diffusive combustion phase; the oxygenated fuel blends lead to an improvement in diffusive combustion for biodiesel and its blends. The highest smoke emissions are 43.1, 36.8, 31.2, 26.4 and 24.2 HSU for B0, B25, B50, B75 and B100 respectively. Reduction in smoke emission of about $14.6 \%$ is recorded at full load for the B25 blend. Another reason of smoke reduction, when using biodiesel is due to the lower $\mathrm{C} / \mathrm{H}$ ratio and absence of aromatic compounds as compared to diesel. The carbon content in biodiesel is lower than diesel fuel. The more carbon a fuel molecule contains, the more likely is to produce soot. Conversely, oxygen within a fuel decreases the tendency of a fuel to produce 
soot [24]. The smoke emission obtained in this study follows the trend as reported by Nantha Gopal et al [25].

\subsection{Combustion Characteristics}

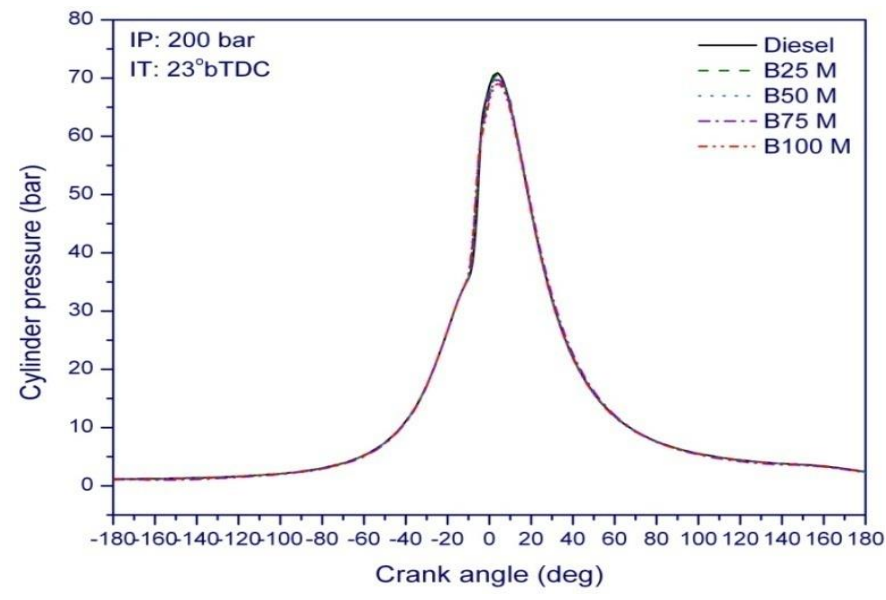

Figure 6 Variation of cylinder pressure with crank angle

The peak pressure mainly depends upon the combustion rate in the initial stages, which is influenced by the fuel taking part in uncontrolled heat release phase. The combustion process of test fuel is similar, consisting of a phase of premixed combustion followed by a phase of diffusion combustion. Premixed combustion phase is controlled by the ignition delay period and spray envelope of the injected fuel [26]. Therefore, the viscosity and volatility of the fuel have a very important role to increase atomization rate and to improve air-fuel mixing formation. The cylinder peak pressure because of the high viscosity and low volatility of biodiesel and its blends is slightly lower than that of diesel fuel. It is observed that the peak pressures of 70.872, 70.553, 69.914, 69.712 and 68.982 bar were recorded for B0, B25, B50, B75 and B100 respectively. However, the cylinder peak pressure of B25 is close to diesel due to the improvement in the preparation of air-fuel mixture as a result of low fuel viscosity [27, 28].

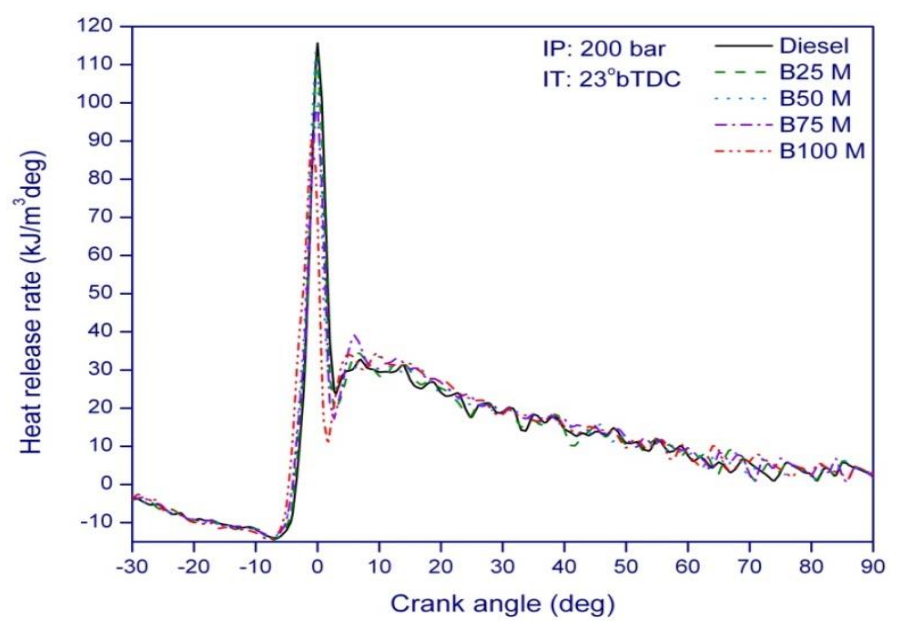

Figure 7 Variation of HRR with crank angle

The variation of heat release rate with crank angle at full load for diesel, biodiesel and its blends are shown in Fig.7. It is observed from the results that the heat release rate for biodiesel and its blends are lower compared to diesel fuel. This may be due to lower calorific value of biodiesel and its blends. However B25 gives more heat release rate than other blends. 
Diesel Engine Performance, Emission and Combustion Characteristics with Optimized Blend of B25 Methyl Ester of Mango Seed Oil

On the other hand, peak heat release rate for B100 is low compared to B25 and this may be due to lower volatility and higher viscosity of B100 [ 29]. The maximum heat release rate of diesel fuel, B25, B50, B75 and B100 is $115.63,112.12,109.26,99.24$ and $90.35 \mathrm{~kJ} / \mathrm{m}^{3} \mathrm{deg}$ respectively. The heat release rate obtained in this study follows the trend as reported by Savariraj et al [30]. A Closer analysis of the heat release rate at higher engine load showed proper utilization of B25 inside the combustion chamber of the engine.

\section{CONCLUSION}

In the present investigation, the performance, emission and combustion characteristics of a direct injection diesel engine fuelled with methyl ester of mango seed oil and its blends have been analyzed and compared with diesel fuel. The results are summarized as follows:

- The BSFC of B25 MEMSO is minimum compared to other blends.

- The BTE of B25 is slightly higher than diesel at all loads.

- The emission of $\mathrm{NO}_{\mathrm{x}}$ is higher than diesel for biodiesel and its blends, but for B25 slight increase of only $5.88 \%$ at full load.

- Reduction of smoke emission for biodiesel and its blends at high loads whereas, for B25 decrease of $14.6 \%$ is observed at full load.

- The peak cylinder pressure and heat release rate of B25 are very close to diesel.

From this investigation, it is concluded that B25 MEMSO is the optimized blend with respect to performance, emission and combustion characteristics for all loads compared with diesel and it could be used as an alternative fuel in a single cylinder direct injection diesel engine without any engine modifications.

\section{REFERENCES}

[1] C.D. Rakopoulos, D.C. Rakopoulos, E.G.Giakoumis and A.M. Dimaratos, Investigation of the combustion of neat cottonseed oil or its neat bio-diesel in a HSDI diesel engine by experimtal heat release and statistical analyses, Journal of Fuel 89 (2010) 3814-3826.

[2] P.Mccarthy, M.G.Rasul and S.Moazzem, Analysis and comparison of performance and emission of an internal combustion engine fuelled with petroleum diesel and different biodiesels, Journal of Fuel 90 (2011) 214-2157.

[3] Sylvester C.Izah and Elijah I.Ohimain, The challenge of biodiesel production from oil palm feedstock in Nigeria, Greener Journal of Biological sciences 3 (2013) 001-012.

[4] Sandeep Singh, Study of various methods of biodiesel production and properties of biodiesel prepared from waste cotton seed oil and waste mustard oil, Thesis of M.E.in Thermal Engineering (2012), Thapar University.

[5] K.M. Shereena and T.Thangaraj, Biodiesel: An alternative fuel produced from vegetalbe oils by transesterification, Electronic Journal of Biology 3 (2009) 67-74.

[6] Dennis Y.C. Leung, Xuan.Wu and M.K.H.Leung, A review on biodiesel production using catalyzed transesterification, Applied Energy 87 (2010) 1083-1095.

[7] P.K Devan and N.V. Mahalakshmi, A study of the performance, emission and combustion characteristics of a compression ignition engine using methyl ester of paradise oileucalyptus oil blends, Applied Energy 86 (2009) 675-680.

[8] Avinash K Hegde and K.V. Sreenivas rao, Performance and emission study of 4S CI engine using Calophyllum Inophyllum biodiesel with additives, International Journal on Theoretical and Applied Research Mechanical Engineering 1 (2012) 1-4. 
[9] Subhash Lahane and K.A. Subramanian, Impact of nozzle holes configuration on fuel spray, wall impingement and $\mathrm{NO}_{\mathrm{x}}$ emission of a diesel engine for biodiesel- diesel blend (B20), Applied Thermal Engg., 64 (2014) 307-314.

[10] D.C Rakopoulos, C.G. Rakopouls, E.G.Giakoumis, A.M.Dimaratos and M.A.Founti, Comparative environmental behavior of bus engine operating on blends of diesel fuel with four straight vegetable oils of Greek origin: sunflower, cottonseed, corn and olive, Journal of Fuel 90 (2011) 3439-3446.

[11] N.Saravanan, G. Nagarajan and S. Puhan, Experimental investigation on a DI diesel engine fuelled with Madhuca Indica ester and diesel blend, Biomass and Bioenergy 34 (2010) 838-843.

[12] L.N.R.Gattamaneni, S. Sravanan, S.Sampath and K.Rajagopal, Combustion and emission characteristics of diesel engine fuelled with rice bran oil methyl ester and its diesel blends, Thermal sci., 12 (2008) 139-150.

[13] K.Rajan and K.R.S. Kumar, Performance and emission characteristics of DI ignition engine with biodiesel using internal jet piston, Environ. Stud., 64 (2010) 1982-1988.

[14] Sharanappa Godiganur, Suryanarayana Murthy and CH.Ranaprathap reddy, 6BTA 5.9 G2-1 Cummins engine performance and emission tests using methyl ester Mahua (Madhuca indica) oil/diesel blends, Renewable Energy 34 (2009) 2172-2177.

[15] T.Balusamy and R. Marappan, Comparative study of Thevetia Peruviana seed oil with other biofuels and diesel as fuel for CI engine, International Journal of Applied Engineering Research, 10 (2008) 93-100.

[16] D.H. Qi, L.M. Geng, H. Chen, Y.Z.H. Bian and J. Liu, Combustion and performance evaluation of a diesel engine fueled with biodiesel produced from soybean crude oil, Renewable Energy, 34 (2009) 2706-2713.

[17] S.Jain and M.P.Sharma, Biodiesel Production from Jatropha Curcas Oil, Renewable and Sust.Energy Reviews, 14 (2011) 3140-47.

[18] M.P. Dorado, E. Ballesteros, F.J. Lopez and Mittelbach, Optimization of alkali-catalyzed transesterification of Brassica carinata oil for biodiesel production. Energy \& Fuels 18 (2004) 77-83.

[19] A.Monyem, H.John and Van Gerpen, The effect of biodiesel oxidation on engine performance and emissions, International Journal of Biomass and Bio Energy 20 (2001) 317-325.

[20] K.Shaine Tyson, Biodiesel handling and use guidelines, U.S.Department of Energy (2004) DOE/GO-10- 2004-1999.

[21] A. Gopinath, Sukumar Puhan and G.Nagarajan, Effect of Unsaturated fatty acid esters of biodiesel fuels on combustion, performance and emission characteristics of a DI diesel engine, International Journal of Energy and Environment, 1 ( 2010) 411-430.

[22] D.Subramaniam, A.Murugesan and A.Avinash, A comparative estimation of CI enginefuelled with methyl esters of punnai, neem and waste cooking oil, International Journal of Energy and Environment, 4, (2013) 859-870.

[23] N. Nabi, M. Rahman and S. Akhter, Biodiesel from cotton seed oil and its effect on engine performance and exhaust emissions, Applied Thermal Eng., 29 (2009) 2265-2270.

[24] J. Xue, T.E. Grift and A.C. Hansen, Effect of Biodiesel on Engine Performances and Emissions, Renewable and Sustainable Energy Reviews, 15 (2011) 1098-1116.

[25] K. Nantha Gopal, Arindam Pal, Sumit Sharma, Charan Samanchi, K.Sathyanarayanan and T.Elango, Investigation of emission and combustion characteristics of a CI engine fueled 
Diesel Engine Performance, Emission and Combustion Characteristics with Optimized Blend of B25 Methyl Ester of Mango Seed Oil

with waste cooking oil methyl ester and diesel blends, Alexandria Engineering Journal 53 (2014) 281-287.

[26] P.K.DevanandN.V.Mahalakshmi, Performance, emission and combustion characteristics of poon oil and its diesel blends in a DI diesel engine, Fuel, 88 (2009) 861- 867.

[27] P.K.Devan and N.V. Mahalakshmi, Study of the performance, emission and combustion characteristics of a diesel engine using poon oil-based fuels, Fuel Process Technol., 90 (2009) 513-519.

[28] A.N Ozsezen, M. Canakci, A. Turkcan and C.Sayin, Performance and combustion characteristics of a DI diesel engine fueled with waste palm oil and canola oil methyl esters, Fuel, 88 (2009) 629-636.

[29] L. Prabhu, S.Sathish Kumar, M.Prabhahar and K.Rajan, Combustion, performance and emission characteristics of diesel engine with neem oil methyl ester and its diesel blends, American Journal of Applied Sciences 10 (2013) 810-818.

[30] S.Savariraj, C.G.Saravanan and T.Ganapathy, Experimental investigation on DI diesel engine powered with raw mango seed oil (MSO) and mango seed biodiesel (MSBD), International Journal of Engineering Research \& Technology 2 (2013) 1516-1523. 